\title{
A Practical Method for Diagnosing the Existence of Industrial Barriers to Entry
}

\author{
Panagiotis Kotsios ${ }^{1, *}$ \\ ${ }^{1}$ Technological Educational Institute of Thessaly, Larisa 41110, Greece \\ *Correspondence: Technological Educational Institute of Thessaly, Larisa 41110, Greece \\ Tel: 30-698-385-2792Ｅ-mail: panagiotiskotsios@gmail.com
}

Received: November 30, 2013 Accepted: January 4, 2014 Published: January 20, 2014

doi:10.5296/rae.v6i1.4643 URL: http://dx.doi.org/10.5296/rae.v6i1.4643

\begin{abstract}
Entry relates with the appearance of a new producer in a market or industrial sector. The role of entry is critical, because it operates as a balancing force against high levels of industrial concentration and the abuse of dominant position by firms with large market shares. The ease of entry is adjusted according to the number and height of barriers to entry. A barrier to entry can be defined as anything that restricts competition in a sector, when more competition would be socially beneficial. The current research proposes a practical method for diagnosing the existence of industrial barriers to entry and for measuring their overall height. The method is based in the principle that profits attract new entrants in an industry, and sectors in which there is an increase of incumbent firms' profitability, without new entry taking place, are cases of sectors with high barriers to entry. The method is applied in six European industrial sectors, based on data taken from Eurostat.
\end{abstract}

Keywords: barriers; entry; competition; industry; diagnostic method 


\section{Introduction}

The current research aims to propose a practical method for diagnosing the existence of industrial barriers to entry and for measuring their overall height. The study begins by explaining what entry is and its role in business and economic activity. It continues with explaining barriers to entry: the term is defined and there is a reference about the barriers' possible categorization methods, the identification of specific barriers and the various measurement methods proposed in the past. Following there is a theoretical explanation of the proposed method and a practical application in 6 European industrial sectors. In the end there is a short discussion about the limitations and weaknesses of the proposed method and the conclusions of the study.

\section{Entry}

The entry of new competitors relates with the appearance of a new producer in a market (OECD, 2005). Entry can take many forms, such as investments in new industrial facilities, exports, trade licenses, joint ventures, strategic alliances, mergers and acquisitions etc. The entry of new competitors operates as a balancing force against high levels of industrial concentration and the abuse of dominant position by firms with large market shares. Entry increases supply, lowers prices, intensifies innovation and restores equilibrium in markets that don't operate in a socially desirable manner.

\section{Barriers to Entry}

The ease of entry is adjusted according to the number and height of barriers to entry. Various definitions of barriers to entry have been proposed in the industrial organization literature, as the ones by Bain (1956), Stigler (1968), Ferguson (1974), Caves \& Porter (1977), Fisher (1979), VonWeizsacker (1980), Demsetz (1982), Baumol \& Willig (1981), Gilbert (1989), Geroski et al (1990), Carlton \& Perloff (1994), Church \& Ware (2000), McAfee et al (2004) and the OECD (2005).

The definition adopted in the current study is the following: a barrier to entry is defined as anything that restricts competition in a sector, when more competition would be socially beneficial. It is based on Fisher's (1979) definition, with a small variation: the phrase "anything that restricts entry" in Fisher's definition was replaced by the phrase "anything that restricts competition". This change was necessary in order to cover cases of mobility barriers from one intersectoral effectiveness group to the other. This definition can include a large number of possible barriers to entry, covers intra- and extra-sector mobility situations and clearly points out the aim of the whole analysis, which is social welfare enhancement. 


\section{Categorization of Barriers to Entry}

In regard to the categorization of barriers to entry, again there have been various proposals in the relevant literature. Howe (1978) separated barriers to natural and technical, Shepherd (1990) separated barriers to indogenous and exogenous and Jacobson \& Andreosso-O'Callaghan (1996) separated barriers in first and second line barriers. The European Competition Commission follows the separation in legal, technical and strategic advantages (as mentioned in the 2004 Horizontal Merger Guidelines).

The most practical separation proposed in the literature was the one by Geroski et al (1990), followed also by the OECD (2005). They separate barriers between structural and strategic. Structural barriers arise from the exogenous demand, cost and technology conditions of an industry and are the same for all firms in a sector, new or incumbent, while strategic barriers, on the other hand, are created from the actions and strategic choices of established firms.

This categorization, even though far from perfect, as some barriers fall in both categories, can still help in an affective analysis of barriers to entry. Examples of structural barriers are economies of scale, capital costs and diversification, while examples of strategic barriers are limit pricing, patent hoarding and collusion.

\section{Definition of Specific Barriers}

The absence of a commonly accepted definition of barriers to entry has caused many arguments on what exactly is a barrier to entry and on how it can be measured. If someone searches the literature on the topic he is going to discover a variety of opinions. Most authors adopt different definitions and examine different barriers.

The first one who worked systematically with barriers to entry, Bain (1956), identified three key barriers: product differentiation, economies of scale and absolute cost advantages. Stigler (1968) considered as a barrier to entry the costs faced by an entrant firm that were not faced by an incumbent firm, without specifying what these costs are and how they can be measured. Caves \& Porter (1977) considered as the most important sources of entry barriers capital requirements, excess capacity, product differentiation, cost advantages, vertical integration, limit pricing and strategic behaviour. VonWeizsacker (1980) in his study examined two barriers, economies of scale and product differentiation.

Baumol \& Willig (1981) argued that fixed costs and economies of scale do not necessarily belong to barriers to entry, but agreed with the view that sunk costs are a very important barrier. Demsetz (1982) placed emphasis on aspects such as legal restrictions on the entry, property rights and predatory pricing. He considered as the most important barrier to entry the high cost of informing consumers and advertising. Gilbert (1989) did not accept economies of scale and absolute cost advantages as significant barriers to entry, if there are no unique factors of production in the possession of established firms. However he considered as significant barriers to entry strategic behaviour and structural advantages such as legal constraints, sunk costs, product differentiation, learning economies and cooperation 
networks. Geroski et al (1990) in their work examined the strategic behaviour of established firms, economies of scale, sunk costs, limit pricing, absolute cost advantages, learning curves and product differentiation.

McAfee et al (2004) argued that economies of scale, capital requirements, capital costs and sunk costs are auxiliary barriers that can prevent entry only in combination with each other, rather than individually. Schmalensee (2004) argued that the barriers to entry can be determined solely by sunk costs. Finally, the OECD (2005) identified and examined a large number of entry barriers, including sunk costs, absolute cost advantages, economies of scale, economies of scope, high capital costs, reputation, cooperation networks, legal barriers, exit barriers, first-mover advantages, vertical integration, limit and predatory pricing, overcapacity, price discounts, product tying, product differentiation, exclusive deals and patent hoarding .

In conclusion it can be observed that throughout the theoretical and empirical literature on barriers to entry, each author has accepted some sources of entry barriers and rejected others, with the exception of the recent OECD study which examines a large number of obstacles. The same confusion is met also in the barriers' measurement methods.

\section{Application and Importance of the Diagnostic Method}

Barriers to entry are important because they are relevant in virtually every kind of competition case. They must be taken into account by competition authorities when measuring monopoly power, assessing dominance, analyzing the likely competitive effects of mergers, intervening in a market in order to fix prices etc. This is because entry barriers may retard, dampen or nullify the market's usual mechanism for balancing market power: the attraction and arrival of new competitors.

For example, if a merger will substantially increase concentration, entry barriers matter because competition will not be reduced if new firms can enter easily, quickly and significantly. Moreover, competition authorities seeking to block a merger will usually need to show that entry barriers make quick and significant entry unlikely. Similarly, establishing the presence of substantial entry barriers is usually necessary to prove that a high market share translates into market power in monopolization or abuse of dominance cases (OECD, 2005).

\section{Barriers to Entry Measurement Methods}

The methods that have been applied in the past for the measurement of entry barriers' height are various. The first attempt was made by Bain (1956). He applied a questionnaire approach in order to investigate managers' perceptions about 3 barriers to entry: economies of scale, product differentiation and absolute cost advantages - including capital costs. He then used the replies received in order to construct a table in which he estimated the barriers' total height for each industry of the sample. The questionnaire approach was followed by other 
authors as Mann (1966), Smiley (1988) and Karakaya \& Stahl (1989).

Other methods that have been proposed for the measurement of barriers to entry are those of Comanor \& Wilson (1967), Salop (1986) and Dunne et al (1988). Comanor \& Wilson (1967) applied an econometric approach in order to investigate the effect of a number of barriers on profitability. Salop (1986) proposed a method based on estimates about entrants' cost and demand disadvantages, entry time duration, sunk costs and economies of scale. Dunne et al (1988) chose to focus on entrants' viability, performance and market impact over a 20 year time period.

The most widely used method for entry barrier measurement is the one primarily proposed by Orr (1974a \& 1974b). Orr, based on Bain's (1956) theses about the relation of entry barriers with profitability, tried to determine the profit level that could be sustained continuously without attracting entry. In order to determine that profit level, he used a multiple regression analysis model in which he investigated the effect of various barriers and entry motives on real entry levels (Geroski et al, 1990; Burton et al, 1999). Following the negative signs of the results, he then constructed an index of the barriers' overall height by adding them. Orr's method has been followed by many other authors, as Gorecki (1975 \& 1976), Duetsch (1984), Khemani \& Shapiro (1986), Geroski (1991), Mata (1993), Yang (1998), Burton et al (1999) etc, with various alterations in the model's sample and variables specification. The major problem with above index is that it doesn't include all the barriers in the sector. The lack of measurement tools for barriers such as legal restrictions, absolute cost advantages, cooperation networks and capital costs, complicate the calculation of all possible barriers to a single index. As a result, the height of the calculated index for each industry, expresses only part of the entry barriers' total height. Moreover, each barrier's measurement method is also an issue in question.

This is why the present study makes a different, more practical proposal for diagnosing the possible existence of entry barriers and assessing their overall height.

\section{Proposed Method}

The proposed method is based on the fundamental, commonly accepted by economic theory, principle that profits attract new entrants in an industry, and new firm entry is the mechanism through which equilibrium is restored in industries where incumbent firms earn excessive profits. Sectors, in which there is an increase of incumbent firms' profitability, without new entry taking place, are cases of sectors with high barriers to entry. Based on this principle, the current study proposes a method for diagnosing the existence of barriers to entry based on a sector's number of firms and profitability.

The existence of entry barriers is diagnosed by using the following simple method: for a fixed period of time ( 5 and 10 year period), the growth rate in the number of firms is compared with the growth rate of profit. If profits increase and the number of firms decreases or remains constant, it is a sign of an industrial sector with high barriers to entry. If profits increase correspondingly to the number of firms, it is a sign of an industrial sector with low 
barriers to entry. In substance, this particular method does not measure the effect and height of particular barriers to entry. It diagnoses the existence of overall barriers to entry in order to assist competition authorities in the process of assessing monopoly power and in measuring the effect of mergers.

\section{Application}

In order to examine the effectiveness of the proposed method, it will be applied in a sample of 6 European industrial sectors. The data used are taken from the Eurostat Structural Business Statistics Database. The industrial sectors are:

- The United Kingdom Production and Preserving of Meat Sector

- The Spanish Manufacture of Footwear Sector

- The German Manufacture of Pharmaceutical Products Sector

- The German Manufacture of Explosives Sector

- The French Manufacture of Chemical Products Sector

- The Finish Manufacture of Agricultural Tractors Sector

For each of these sectors there is a table that presents the number of firms and the gross operating surplus for a 10 year period (1999-2008). Gross operating surplus has been used in order to approximate profits. Gross operating surplus, as defined by Eurostat in the context of structural business statistics, is gross output less the cost of intermediate goods and services (to give gross value added) and less compensation of employees. It is gross because it makes no allowance for consumption of fixed capital. This variable was the closest one to net profits that could be retrieved from the Eurostat database, and that is the reason it is used. It has to be noted however, that the most suitable variable would be net profits, and if Competition Commissions have access to net profit data, they should definitely prefer them.

For both variables there is a separate column that measures the percentage change in the number of firms and profits for a 5 and 10 year time period, taking as base year 1999. The percentage change between the two variables is compared and related to barriers to entry according to the following scale:

Table 1. Scale for Assessing Entry Barriers' Overall Height

\begin{tabular}{cc}
\hline $\begin{array}{c}\text { Difference between Number of Firms and } \\
\text { Profits variables }\end{array}$ & $\begin{array}{c}\text { Possible Overall Height of } \\
\text { Industrial Barriers to Entry }\end{array}$ \\
\hline $0 \%-33 \%$ & Low \\
$34 \%-66 \%$ & Medium \\
$67 \%+$ & High \\
\hline
\end{tabular}




\section{Macrothink

This scale serves the purpose of providing the thresholds according to which the overall height of barriers to entry in a sector can be characterized as low, medium of high. Overall entry barriers' height is characterized as low when the difference between the percentage change in the number of firms and profits is between $0 \%$ and $33 \%$, as medium when it is between $34 \%-66 \%$ and high when it equals or exceeds $67 \%$. The results of the analysis are presented below.

Table 2. Number of Enterprises and Gross Operating Surplus in the United Kingdom Production and Preserving of Meat Industrial Sector

\begin{tabular}{ccccc}
\hline \multicolumn{5}{c}{ UK - PRODUCTION AND PRESERVING OF MEAT } \\
\hline Year & $\begin{array}{c}\text { Number of } \\
\text { enterprises }\end{array}$ & $\begin{array}{c}\text { 5 and 10 } \\
\text { year \% } \\
\text { change }\end{array}$ & $\begin{array}{c}\text { Gross operating } \\
\text { surplus (m } \boldsymbol{€})\end{array}$ & $\begin{array}{c}\text { 5 and 10 } \\
\text { year \% } \\
\text { change }\end{array}$ \\
\hline 1999 & 433 & & 283,9 & \\
2000 & 400 & & 240,0 & \\
2001 & 398 & & 281,9 & \\
2002 & 390 & $-34,64$ & 197,7 & $-3,70$ \\
2003 & 283 & & 273,4 & \\
2004 & 296 & & 353,0 & \\
2005 & 306 & & 408,1 & \\
2006 & 286 & & 486,3 & \\
2007 & 296 & & 631,3 & \\
2008 & 297 & $-31,41$ & $631,3 *$ & $+122,37$ \\
\hline
\end{tabular}

Source: Eurostat *Estimate

From Table 2 we can observe that, taking 1999 as the base year, the number of enterprises in the UK production and preserving of meat industry has been reduced $-34 \%$ during the following 5 year period and $-31 \%$ in the following 10 year period. Gross profits on the other hand have been reduced $-3,7 \%$ in the following 5 year period, but increased $+122 \%$ during the following 10 year period. From the difference of the percentages in the 10 year period we can conclude the possible existence of high barriers to entry in the sector from 2004 onwards. This is because there is simultaneous decrease in the number of firms and very high increase in the rate of profit. The difference between the two percentages is $153 \%$, which on 2008 would place the industry in the high barrier scale. 
Table 3. Number of Enterprises and Gross Operating Surplus in the Spanish Manufacture of Footwear Industrial Sector

\begin{tabular}{ccccc}
\hline \multicolumn{5}{c}{ SPAIN - MANUFACTURE OF FOOTWEAR } \\
\hline Year & $\begin{array}{c}\text { Number of } \\
\text { enterprises }\end{array}$ & $\begin{array}{c}\mathbf{5} \text { and 10 } \\
\text { year \% } \\
\text { change }\end{array}$ & $\begin{array}{c}\text { Gross operating } \\
\text { surplus (m } \boldsymbol{~})\end{array}$ & $\begin{array}{c}\text { 5 and 10 } \\
\text { year \% } \\
\text { change }\end{array}$ \\
\hline 1999 & 5.610 & & 266,7 & \\
2000 & 5.443 & & 260,9 & \\
2001 & 4.805 & & 250,4 & \\
2002 & 4.675 & & 232,0 & $-0,34$ \\
2003 & 4.418 & $-21,25$ & 265,8 & \\
2004 & 4.556 & & 218,3 & \\
2005 & 4.389 & & 217,5 & \\
2006 & 4.276 & & 233,5 & \\
2007 & 4.097 & & 214,0 & \\
2008 & 4.111 & $-26,72$ & 239,2 & $-10,31$ \\
\hline
\end{tabular}

Source: Eurostat

In Table 3 we notice that in the Spanish manufacture of footwear industrial sector the number of enterprises has decreased -21\% between 1999 and 2003, and -26\% from 1999 to 2008. Profits on the other hand have remained almost stable for the 5 year period after 1999, and decreased $-10 \%$ after 10 years. As observed from the data, this sector has low barriers to entry, as the decrease in the number of firms is accompanied by a decrease in profits and the percentage change between the two variables is $16 \%$. This percentage places the sector in the low barriers to entry threshold mentioned earlier.

Table 4. Number of Enterprises and Gross Operating Surplus in the German Manufacture of Pharmaceutical Products Industrial Sector

\begin{tabular}{|c|c|c|c|c|}
\hline \multicolumn{5}{|c|}{ GERMANY - MANUFACTURE OF PHARMACEUTICAL PRODUCTS } \\
\hline Year & $\begin{array}{l}\text { Number of } \\
\text { enterprises }\end{array}$ & $\begin{array}{l}5 \text { and } 10 \\
\text { year } \% \\
\text { change }\end{array}$ & $\begin{array}{c}\text { Gross operating } \\
\text { surplus (m } € \text { ) }\end{array}$ & $\begin{array}{l}5 \text { and } 10 \\
\text { year } \% \\
\text { change }\end{array}$ \\
\hline 1999 & 37 & & 66,0 & \\
\hline 2000 & 37 & & 133,7 & \\
\hline 2001 & 42 & & 118,0 & \\
\hline 2002 & 23 & & 101,4 & \\
\hline 2003 & 68 & $+83,78$ & 164,2 & $+148,79$ \\
\hline 2004 & 79 & & 142,0 & \\
\hline 2005 & 65 & & 166,2 & \\
\hline 2006 & 66 & & 207,2 & \\
\hline 2007 & 74 & & 226,8 & \\
\hline 2008 & 78 & $+110,81$ & 226,8 & $+243,64$ \\
\hline
\end{tabular}

Source: Eurostat 


\section{Macrothink

From Table 4 we can see that in the German pharmaceutical sector there was an increase in the number of firms, both during the 5 year $(+83 \%)$ and 10 year period $(+110 \%)$. Also there has been an increase in profits $(+148 \%$ in 5 year and $+243 \%$ in 10 year period). As the increases in these two variable are not proportional (actually the increase in profits is almost double that the increase in the number of firms), we can diagnose the possible existence of considerable barriers to entry (difference of $133 \%$ ).

In Table 5 for we notice that the number of firms in the German explosives sector has increased $+9 \%$ during the 5 and 10 year period after the base year 1999. Profits on the other hand have increased $+42 \%$ in the following 5 year period and $+67 \%$ in the following 10 year period. This is a sign of the possible existence of medium barriers to entry in the sector (difference of 58\%).

Table 5. Number of Enterprises and Gross Operating Surplus in the German Manufacture of Explosives Industrial Sector

\begin{tabular}{ccccc}
\hline \multicolumn{5}{c}{ GERMANY - MANUFACTURE OF EXPLOSIVES } \\
\hline Year & $\begin{array}{c}\text { Number of } \\
\text { enterprises }\end{array}$ & $\begin{array}{c}\text { 5 and 10 } \\
\text { year \% } \\
\text { change }\end{array}$ & $\begin{array}{c}\text { Gross operating } \\
\text { surplus (m } € \text { ) }\end{array}$ & $\begin{array}{c}\text { 5 and 10 } \\
\text { year \% } \\
\text { change }\end{array}$ \\
\hline 1999 & 22 & & 107,3 & \\
2000 & 20 & & 121,0 & \\
2001 & 26 & & 96,9 & \\
2002 & 16 & & 147,1 & \\
2003 & 24 & & 152,7 & $+42,31$ \\
2004 & 28 & & 176,6 & \\
2005 & 22 & & 165,4 & \\
2006 & 22 & & 156,4 & \\
2007 & 21 & & 179,8 & \\
2008 & 24 & $+9,09$ & 179,8 & $+67,57$ \\
\hline
\end{tabular}

Source: Eurostat

From Table 6 we observe that in the French chemical sector industry the number of firms has decreased $-1,7 \%$ between 1999 and 2003, and -14\% between 1999 and 2008. On the other hand profits decreased $-1 \%$ between 1999 and 2003, and increased $+27 \%$ between 1999 and 2008. This $41 \%$ difference in the percentages is a sign of the existence of medium barriers to entry. 
Table 6. Number of Enterprises and Gross Operating Surplus in the French Manufacture of Chemical Products Industrial Sector

\begin{tabular}{ccccc}
\hline \multicolumn{5}{c}{ FRANCE - MANUFACTURE OF CHEMICAL PRODUCTS } \\
\hline Year & $\begin{array}{c}\text { Number of } \\
\text { enterprises }\end{array}$ & $\begin{array}{c}\mathbf{5} \text { and 10 } \\
\text { year \% change }\end{array}$ & $\begin{array}{c}\text { Gross operating } \\
\text { surplus (m } € \text { ) }\end{array}$ & $\begin{array}{c}\text { 5 and 10 } \\
\text { year \% } \\
\text { change }\end{array}$ \\
\hline 1999 & 4.017 & & $9.680,2$ & \\
2000 & 3.953 & & $10.180,1$ & \\
2001 & 3.917 & & $9.724,0$ & \\
2002 & 3.898 & & $8.837,6$ & $-1,04$ \\
2003 & 3.948 & $-1,72$ & $9.579,7$ & \\
2004 & 3.919 & & $9.375,8$ & \\
2005 & 3.848 & & $9.717,8$ & \\
2006 & 3.759 & & $11.865,1$ & \\
2007 & 3.868 & & $12.363,7$ & \\
2008 & 3.440 & $-14,36$ & $12.363,7$ & $+27,72$ \\
\hline
\end{tabular}

Source: Eurostat

Finally in Table 7 we observe that in the Finnish agricultural tractors sector the number of firms has decreased $-6 \%$ between 1999 and 2003 and -23\% between 1999 and 2008. On the other hand, profits increased $+260 \%$ between 1999 and 2003 and $+430 \%$ between 1999 and 2008. This $453 \%$ difference in the percentages is a sign of the possible existence of high barriers to entry in the sector.

Table 7. Number of Enterprises and Gross Operating Surplus in the Finish Manufacture of Agricultural Tractors Industrial Sector

\section{FINLAND - MANUFACTURE OF AGRICULTURAL TRACTORS}

\begin{tabular}{ccccc}
\hline Year & $\begin{array}{c}\text { Number of } \\
\text { enterprises }\end{array}$ & $\begin{array}{c}\mathbf{5} \text { and 10 } \\
\text { year \% change }\end{array}$ & $\begin{array}{c}\text { Gross operating } \\
\text { surplus (m } \boldsymbol{\epsilon})\end{array}$ & $\begin{array}{c}\mathbf{5} \text { and 10 } \\
\text { year \% } \\
\text { change }\end{array}$ \\
\hline 1999 & 166 & & $-17,2$ & \\
2000 & 163 & & 33,4 & \\
2001 & 166 & & 21,5 & \\
2002 & 160 & & 32,9 & $+260,47$ \\
2003 & 155 & $-6,63$ & 27,6 & \\
2004 & 147 & & 23,2 & \\
2005 & 140 & & 33,6 & \\
2006 & 137 & & 41,2 & \\
2007 & 134 & & 56,9 & $+430,81$ \\
2008 & 127 & $-23,49$ & 56,9 & \\
\hline
\end{tabular}

Source: Eurostat 


\section{Limitations and Weaknesses}

This diagnostic method is practical and easy to use as a screening method for the possible existence of industrial barriers to entry. It also serves the purpose of approximating the barriers' possible overall height. However, it offers no insight on which are the exact barriers that delay or block the entry of new competitors in the industry. The discovery of the exact barriers met by new firms requires extensive and thorough research in the sector and its parameters.

Another important limitation comes from the use of gross operating surplus as the profit variable. This variable was not the most suitable for the purposes of this research, but it was used due to the fact that net profit data were not available from Eurostat website. If national authorities have access to net profit data, they should use them in order to make the results of the diagnostic method more accurate.

\section{Conclusions}

Competition Authorities around the world, while carrying out their duties, need to identify the possible existence of barriers to entry and assess their height. Various measurement methods have been proposed in the Industrial Organization literature in the past, and each one has its own advantages and disadvantages. They depend largely on the definition adopted by each author and the barriers he identified.

This study suggests a practical and easy to use method for diagnosing the possible existence of overall barriers to entry and assessing their height. It is based on comparisons between the growth rate in the number of firms and the growth rate of profit for a fixed period of time. The difference between the two rates classifies sectors in three possible barriers to entry scales: low, medium and high. The main weakness of the method is that measures the effect of the overall barriers, without pointing which these barriers are and what their effect is.

\section{References}

Bain, J. (1956). Barriers to new competition. Harvard University.

Baumol, W., \& Willig, R. (1981). Fixed cost, sunk cost, entry barriers and sustainability of monopoly. Quarterly Journal of Economics, 96(3), 405-431. http://dx.doi.org/10.2307/1882680

Burton, M., Kaserman, D., \& Mayo J. (1990). Modelling entry and barriers to entry: a test of alternative specifications. The Antitrust Bulletin, 44(2), 387-420.

Carlton, D., \& Perloff, J. (1994). Modern industrial organization. New York: Harper Collins College Publishers.

Caves, R., \& Porter, M. (1977). From entry barriers to mobility Barriers: Conjectural Decisions and Contrived Deterrence to New Competition. Quarterly Journal of 
Economic, 91(2), 247-261. http://dx.doi.org/10.2307/1885416

Church, J., \& Ware, R. (2000). Industrial organization: a strategic approach. Mc Graw Hill.

Comanor, W., \& Wilson, T. (1967). Advertising, market structure and performance. Review of Economics and Statistics, 49(4), 423-440. http://dx.doi.org/10.2307/1928327

Demsetz, H. (1982). Barriers to entry. American Economic Review, 72(1), 47-57.

Duetsch, L. (1984). An examination of industry exit patterns. The Review of Industrial Organization, 1(1), 60-68. http://dx.doi.org/10.1007/bf02354135

Dunne, T., Roberts, M., \& Samuelson, L. (1988). Patterns of firm entry and exit in U.S. manufacturing industries. The Rand Journal of Economics, 19(4), 495-515. http://dx.doi.org/10.2307/2555454

European Commission (2004). Guidelines on the Assessment of Horizontal Mergers under the Council Regulation on the Control of Concentrations Between Undertakings (2004/C $31 / 03)$.

Eurostat (2013). Structural Business Statistics Retrieved from http://epp.eurostat.ec.europa.eu (October 10, 2013).

Ferguson, J. (1974). Advertising and competition: theory, measurement, fact. Cambridge: Ballinger.

Fisher, F. M. (1979). Diagnosing monopoly. Quarterly Review of Economics and Business, 19(2), 7-33.

Geroski, P. (1991). Domestic and foreign entry in the United Kingdom: 1983-1964. In P. Geroski \& J. Schwalbach (Eds.), Entry and Market Contestability (63-88), Oxford: Basil Blackwell.

Geroski, P., Gilbert, R., \& Jacquemin, A. (1990). Barriers to entry and strategic competition. New York: Harwood Academic Publishers.

Gilbert, R. (1989). Mobility barriers and the value of incumbency. In R. Schmalensee \& R. D. Willig (Eds.) Handbook of Industrial Organization (476-535). Amsterdam: North-Holland.

Gorecki, P. (1976). The determinants of entry by domestic and foreign enterprises in canadian manufacturing industries: some comments and empirical results. The Review of Economics and Statistics, 58(4), 485-488. http://dx.doi.org/10.2307/1935882

Gorecki, P. K, (1975). The determinants of entry by new and diversifying enterprises in the U.K. manufacturing sector 1958-1963: some tentative results. Applied Economics, 7(2), 139-147. http://dx.doi.org/10.1080/00036847500000015

Howe, W. S. (1978). Industrial economics. London: McMillan.

Jacobson, D., \& Andreosso-O'Callaghan, B. (1996). Industrial economics and organisation: 
a European perspective. London: Macmillan.

Karakaya, F., \& Stahl, M. (1989). Barriers to entry and market entry decisions in consumer and industrial goods markets. Journal of Marketing, 53(2), 80-91. http://dx.doi.org/10.2307/1251415

Khemani, R. S, \& Shapiro D. M. (1986). The determinants of new plant entry in Canada. Applied Economics, 18(11), 1243-1257. http://dx.doi.org/10.1080/00036848600000077

Mann, H. M. (1966). Seller concentration, barriers to entry, and rates of return in 30 industries. Review of Economics and Statistics, 48(3), 296-307. http://dx.doi.org/10.2307/1927085

Mata, J. (1993). Entry and type of entrant: evidence from Portugal. International Journal of Industrial Organization, 11(1), 101-122. http://dx.doi.org/10.1016/0167-7187(93)90038-e

McAfee, R. P., Mialon, H., \& Williams, M. (2004). What is a barrier to entry?. American Economic Review, Papers and Proceedings, 94(2), 461-465. http://dx.doi.org/10.2139/ssrn.594601

Organisation for the Economic Cooperation and Development (2005). Barriers to Entry, Policy Roundtables, DAF/COMP(2005)42.

Orr, D. (1974a). The determinants of entry: a study of the Canadian manufacturing industries. Review of Economics and Statistics, 56(1), 58-66. http://dx.doi.org/10.2307/1927527

Orr, D. (1974b). An index of entry barriers and its application to the market structure performance relationship. Journal of Industrial Economics, 23(1), 39-49. http://dx.doi.org/10.2307/2098211

Salop, S. (1986). Measuring ease of entry. The Antitrust Bulletin, 31(2), 551-563.

Schmalensee, R. (2004). Sunk costs and antitrust barriers to entry. American Economic Review, Papers and Proceedings of the One Hundred Sixteenth Annual Meeting of the American Economic Association San Diego, CA, 94(2), 471-475. http://dx.doi.org/10.1257/0002828041301975

Shepherd, W. (1990). The economics of industrial organization ( $3^{\text {rd }}$ Edition). London: Prentice-Hall International.

Smiley, R. (1988). Empirical evidence on strategic entry deterrence. International Journal of Industrial Organization, $6(2)$ 167-180. http://dx.doi.org/10.1016/s0167-7187(88)80023-7

Stigler, G. (1968). The Organization of Industry. Richard D. Irwin: Homewood, Ill.

VonWeizsacker, C. A. (1980). A welfare analysis of barriers to entry. Bell Journal of Economics, 1(2), 399-420. http://dx.doi.org/10.2307/3003371

Yang, G. B. (1998). Barriers to entry and industrial performance in China. International 
Review

of

Applied

Economics, 2014, Vol. 6, No. 1

http://dx.doi.org/10.1080/026921719800000024

\section{Copyright Disclaimer}

Copyright reserved by the author(s).

This article is an open-access article distributed under the terms and conditions of the Creative Commons Attribution license (http://creativecommons.org/licenses/by/3.0/). 